\title{
Molecular phylogeny of the stingless bees (Apidae, Apinae, Meliponini) inferred from mitochondrial 16S rDNA sequences
}

\author{
Marco A. Costa ${ }^{a *}$, Marco A. Del LAMA ${ }^{a}$, Gabriel A.R. MELO ${ }^{b}$, Walter S. SHEPPARD ${ }^{c}$ \\ a Departamento de Genética e Evolução, Universidade Federal de São Carlos, Via Washington Luís, Km 235, São \\ Carlos, SP 13565-905, Brazil \\ b Departamento de Zoologia, Universidade Federal do Paraná, Cx. Postal 19020, Curitiba, PR, 81531-980, Brazil \\ c Department of Entomology, Washington State University, Pullman, WA 99164-6382, USA
}

(Received 25 April 2002; revised 26 June 2002; accepted 17 September 2002)

\begin{abstract}
Sequence data from the mitochondrial 16S rDNA of 34 species from 22 genera of stingless bees plus outgroup sequences from 11 species of other corbiculate bees were used to investigate the phylogenetic relationships among the Meliponini. Equally weighted parsimony and maximum likelihood analyses were performed. Four main clades were recognized in the parsimony consensus tree: (A) Hypotrigona, (B) Austroplebeia, (C) remaining African genera (Plebeina, Meliplebeia, and Axestotrigona) plus the two Oriental genera (Lepidotrigona and Heterotrigona), and (D) Neotropical genera. The African genus Hypotrigona was placed as the most basal branch in the tribe, followed by Austroplebeia as the sister group of other two major clades $(\mathrm{C}$ and $\mathrm{D})$. Our results did not support traditional groups with intercontinental composition, e.g. Trigona sensu lato or Plebeia sensu lato.
\end{abstract}

stingless bees / Meliponini / 16S rDNA / phylogeny

\section{INTRODUCTION}

Meliponini is a tribe of highly social stingless honey bees. Although the tribe has a pantropical distribution, most species are restricted to the Neotropical region (ca. 75\% of the approximately 500 known species). Meliponini are easily distinguished from other tribes of the subfamily Apinae by the reduced wing venation, presence of a penicillum (a brush of long setae on the outer, apical surface of the hind tibia), and a vestigial sting (Wille, 1979, 1983; Michener, 1990, 2000), among many other features. A major character that separates Meliponini from other corbiculate tribes is the absence of an auricle on the hind basitarsus. The species included in the tribe show considerable variety in size, nesting sites, and nest architecture (Michener, 1974; Sakagami, 1982). The female castes, queen and worker, differ strikingly in morphology (Michener, 1974; Wille, 1979).

Different generic classifications have been proposed for this tribe over the past 50 years (e.g. Michener, 1944; Schwarz, 1948; Moure, 1951, 1961). The first cladistic hypothesis

\footnotetext{
* Correspondence and reprints

E-mail: costama@uesc.br

Current address: Departamento de Ciências Biologicas, Universidade Estadual de Santa Cruz Rodovia

Ilhéus-Itabuna, km 16, Ilhéus, Bahia 45650-000, Brazil.
} 
based on an analysis of 17 morphological characters was proposed by Michener (1990). He recognized a total of 35 taxa at the genus and subgenus level. Camargo and Pedro (1992a) reanalyzed the same characters and proposed an alternative hypothesis in which 55 genera were recognized. More recently a new genus, Meliwillea, endemic to Central American cloud forests was described by Roubik et al. (1997). Both phylogenetic hypotheses recognize groups with intercontinental composition. Trigona sensu Michener (1990, 2000), for example, includes Neotropical, as well as Indomalayan taxa.

Michener's and Camargo and Pedro's hypotheses have several major disagreements. In Michener's (1990) analysis, the Neotropical genus Melipona comes out as the sister group of the remaining Meliponini, and the Australian genus Austroplebeia appears related to the African forms. In Camargo and Pedro (1992a), these two genera are placed among several Neotropical genera related to Plebeia. Moreover, doubtful relationships appear among the minute Hypotrigona-like bees that include Neotropical, African and Indomalayan forms and which are placed as closely related taxa in Michener's cladograms. According to Moure (1961), character convergence associated with reduction of size could have occurred within this group.

Despite these recent studies, the relationships among the meliponine genera remain poorly understood. The utility of DNA sequence data to resolve Meliponini phylogenetic relationships is still to be evaluated. Sequence data from the mitochondrial $16 \mathrm{~S}$ rRNA gene have been used previously at higher-level phylogenetic studies within the order Hymenoptera (Cameron, 1991, 1993; Derr et al. 1992a, b; Dowton and Austin, 1994, 2001; Dowton et al., 1997; Koulianos et al., 1999; Cameron and Mardulyn, 2001). In the present study, we used 16S rDNA sequence data to investigate the phylogenetic relationships among 22 of the 56 genera of Meliponini recognized by Camargo and Pedro (1992a) and Roubik et al. (1997).

\section{MATERIALS AND METHODS}

We examined sequence data from the mitochondrial 16S rDNA of 34 species of Meliponini, repre- senting 22 genera. Available GenBank sequences from four species of Apis, four of Bombus and three of euglossine bees (Euglossa, Eufriesea and Eulaema) were included as outgroups in the analysis. A list of the species analyzed is shown in Table I.

Total nucleic acid extraction followed the protocol of Sheppard and McPheron (1991), with a few modifications. For each extraction, a single bee thorax was homogenized in $100 \mu \mathrm{L}$ of buffer in a $1.5 \mathrm{~mL}$ microcentrifuge tube. The final pellet was resuspended in $50 \mu \mathrm{L}$ of TE buffer $(10 \mathrm{mM}$ Tris, $0.1 \mathrm{mM}$ EDTA, pH 8.0). DNA templates were amplified by polymerase chain reaction on an ERICOMP thermocycler performing 40 amplification cycles $\left(94{ }^{\circ} \mathrm{C}, 1 \mathrm{~min} ; 42{ }^{\circ} \mathrm{C}, 1.5 \mathrm{~min}\right.$; and $64{ }^{\circ} \mathrm{C}$, $1.5 \mathrm{~min}$ ), followed by a final extension step at $72{ }^{\circ} \mathrm{C}$ for $5 \mathrm{~min}$. PCR amplifications were carried out in $25 \mu \mathrm{l}$ total reaction volumes using $2.5 \mu \mathrm{l}$ of reaction buffer, $4 \mu \mathrm{L}$ of dNTP mixture (final concentration of $200 \mu \mathrm{M}$ each), $1 \mu \mathrm{L}$ of each primer, 1 unit of Taq polymerase (Promega), 1 or $2 \mu \mathrm{L}$ of DNA template, and sterile water.

For DNA amplification, we designed the following two primers based on available sequences from the honey bee 16S rDNA: LR13943F 5'-CACCTGTTTATCAAAAACAT-3' and LR13392R 5'-CGTCGATTTGAACTCAAATC3'. Sequences corresponding to nucleotides 13392 through 13943 of the honey bee mitochondrial genome (Crozier and Crozier, 1993) were obtained by direct sequencing of double-stranded amplified DNA fragments of about $550 \mathrm{bp}$. Sequencing followed the Sanger method (Sanger et al., 1977) using T7 Sequenase version 2.0 (Amersham Co.). Electrophoresis was carried out on $6 \%$ polyacrylamide sequencing gels (Long Ranger Gel - AT Biochem, Malvern, PA), $0.5 \mathrm{X}$ and $1 \mathrm{X}$ TBE upper and lower tray respectively, $2400 \mathrm{~V}$ at $50^{\circ} \mathrm{C}$ for 2 hours. Afterwards, gels were rinsed in deionized water, dried and exposed to X-ray film at room temperature for 24 hours. The new sequences obtained were deposited in GenBank (http://www.ncbi.nlm.nih.gov) under accession numbers AF343091-AF343118 (see Tab. I).

Alignment of the sequences was performed using the program CLUSTAL W (Thompson et al., 1994) and adjusted by hand to optimize the alignments of gaps. Gaps were treated as missing data in the parsimony analyses. Maximum parsimony analysis was performed using the program PAUP* 4 b8a (Swofford, 2001) for Windows. Branch support was evaluated by jackknife [37\% of characters removed per search, as suggested by Farris et al. (1996)] and bootstrap proportions, calculated on a data matrix with invariant and autapomorphic positions removed. The following command strings were used in PAUP 
Table I. List of the species, origin and type of sample used for DNA extraction or source of sequence data used in the analysis. $\mathrm{E}=$ ethanol-preserved sample; $\mathrm{D}=$ dry sample.

\begin{tabular}{|c|c|c|c|}
\hline Taxon & Abbreviated name & $\begin{array}{l}\text { Accession } \\
\text { Number }\end{array}$ & $\begin{array}{c}\text { Locality data or } \\
\text { Original reference }\end{array}$ \\
\hline Austroplebeia australis & A. australis & AF343112 & Duaringa, Australia [E] \\
\hline Austroplebeia symei & A. symei & AF343113 & GinGin, Australia [E] \\
\hline Axestotrigona togoensis & Axestotrigona & AF343117 & Harare, Zimbabwe [D] \\
\hline Friesella schrotkyi & Friesella & AF343099 & Viçosa, MG, Brazil [E] \\
\hline Frieseomelitta doederleini & Frieseomelitta & AF343101 & Bom Jesus, PI, Brazil [E] \\
\hline Heterotrigona itama & Heterotrigona & AF343115 & Chartaburi, Thailand [D] \\
\hline Hypotrigona gribodoi & Hypotrigona & AF343114 & Northern Prov., South Africa [D] \\
\hline Lepidotrigona ventralis & Lepidotrigona & AF343118 & Chiang Mai, Thailand [D] \\
\hline Lestrimelitta sp.* & Lestrimelitta & AF181586 & Cameron and Mardulyn (2001) \\
\hline Lestrimelitta limao & L. limao & AF343106 & Ribeirão Preto, SP, Brazil [E] \\
\hline Meliplebeia becarii & Meliplebeia & AF343109 & Mgahinga, Uganda [D] \\
\hline Melipona compressipes & M. compressipes & AF181589 & Cameron and Mardulyn (2001) \\
\hline M. quadrifasciata & M. quadrifasciata & AF343100 & Viçosa, MG, Brazil [E] \\
\hline Meliwillea bivea & Meliwillea & AF343108 & Zurqui, Costa Rica [D] \\
\hline Nannotrigona testaceicornis & Nannotrigona & AF343102 & Viçosa, MG, Brazil [E] \\
\hline Oxytrigona tataira & Oxytrigona & AF343104 & Cajuru, SP, Brazil [E] \\
\hline Paratrigona subnuda & Paratrigona & AF343105 & C. do Castelo, ES, Brazil [D] \\
\hline Partamona helleri & Partamona & AF343098 & Viçosa, MG, Brazil [E] \\
\hline Plebeia droryana & P. droryana & AF343092 & Viçosa, MG, Brazil [E] \\
\hline P. julianii & P. julianii & AF343096 & Londrina, PR, Brazil [E] \\
\hline P. nigriceps & P. nigriceps & AF343094 & Pres. Prudente, SP, Brazil [E] \\
\hline P. remota & P. remota & AF343097 & Cunha, SP, Brazil [E] \\
\hline P. saiqui & P. saiqui & AF343093 & Cunha ,SP, Brazil [E] \\
\hline P. wittmmanni & P. wittmanni & AF343095 & Canguçu, RS, Brazil [E] \\
\hline Plebeia denoiti & Plebeina & AF343116 & Harare, Zimbabwe [D] \\
\hline Scaptotrigona depilis & S. depilis & AF181588 & Cameron and Mardulyn (2001) \\
\hline S. luteipennis & S. luteipennis & L22900 & Cameron (1993) \\
\hline S. subobscuripennis & S. subobscuripennis & AF343103 & Zurqui, Costa Rica [D] \\
\hline Scaura latitarsis & Scaura & AF343111 & Ribeirão Preto,SP, Brazil [E] \\
\hline Schwarziana quadripunctata & Schwarziana & AF343110 & Viçosa, MG, Brazil [E] \\
\hline Tetragonisca angustula & Tetragonisca & AF343107 & Viçosa, MG, Brazil [E] \\
\hline Trigona amalthea & T. amalthea & AF214667 & Tanaka et al. (2001) \\
\hline T. fuscipennis & T. fuscipennis & AF343091 & Ribeirão Preto, SP, Brazil [E] \\
\hline T. hypogea & T. hypogea & L22901 & Cameron $(1993)$ \\
\hline Apis cerana & A. cerana & AF153089 & Tanaka et al. (2001) \\
\hline A. dorsata & A. dorsata & AF153098 & Tanaka et al. (2001) \\
\hline A. florea & A. florea & L22894 & Cameron (1993) \\
\hline A. mellifera & A. mellifera & AF214666 & Tanaka et al. (2001) \\
\hline Bombus avinoviellus & B. avinoviellus & L22897 & Cameron (1993) \\
\hline B. pennsylvanicus & B. pennsylvanicus & L22896 & Cameron (1993) \\
\hline B. terrestris & B. terrestris & AF181582 & Cameron and Mardulyn (2001) \\
\hline B. variabilis & B. variabilis & L22898 & Cameron (1993) \\
\hline Eufriesea caerulescens & E. caerulescens & L22904 & Cameron (1993) \\
\hline Euglossa imperialis & E. imperialis & AF181584 & Cameron and Mardulyn (2001) \\
\hline Eulaema polychroma & E. polychroma & L22903 & Cameron $(1993)$ \\
\hline
\end{tabular}

* Cited as Lestrimelitta limao by Cameron and Mardulyn (2001), but this species does not occur in Central America, being restricted to southeastern Brazil. 
to obtain, respectively, the jackknife and bootstrap proportions: "jackknife pctdelete $=37$ nreps $=100$ search $=$ heuristic/ nreps $=2$ addseq = random" and "bootstrap nreps $=100$ search $=$ heuristicl nreps $=2$ addseq $=$ random".

Model selection for the maximum likelihood (ML) analyses was carried out using the program Modeltest Version 3.06 (Posada and Crandall, 1998, 2001). The likelihood settings in PAUP were adjusted to implement a transversional model with gamma distributed rates $(\mathrm{TVM}+\mathrm{G})$, the best-fit model selected by hierarchical likelihood ratio tests in Modeltest. The following PAUP block was added at the end of the input file: lset base = (0.4306 0.04990 .1209$) \quad n s t=6$ rmat $=(1.8757$ $7.03895 .08513 .89667 .0389)$ rates $=$ gamma shape $=0.3421$ pinvar $=0$.

\section{RESULTS}

The length of the 16S rDNA fragments sequenced in the present study and used in the phylogenetic analyses varied from 320 (for Hypotrigona) to $421 \mathrm{bp}$ (for Frieseomelitta). Most species had between 410 and 420 bp sequenced and only three species had less than $390 \mathrm{bp}$. The length of the sequences taken from GenBank varied from 458 ( $T$. amalthea) to 479 bp (Euglossa imperialis). The partial sequences of the 45 taxa resulted in a data matrix of 462 aligned bases. The aligned sequences can be obtained from the first author upon request. Variation among the taxa occurred in 259 base positions, with 72 characters being autapomorphic. A high $\mathrm{A}+\mathrm{T}$ content was observed $(81.4 \%)$. The uncorrected sequence divergence among Meliponini ranged from 1 to $19 \%$.

Exclusion of autapomorphies and invariant characters from the data set left 187 informative sites for the parsimony analysis. Equally weighted parsimony analysis resulted in 6 most parsimonious trees of 901 steps with a consistency index of 0.33 and a retention index of 0.55 . The strict consensus tree is shown in Figure 1. Previous hypotheses of relationships among the corbiculate Apinae were not taken into consideration for tree rooting: the tree root was simply placed between the ingroup and outgroup. Previous molecular and morphological studies on the phylogeny of the corbiculate Apinae (Apini, Euglossini, Bombini and Meliponini) have produced con- flicting results and readers interested in these relationships should consult recent studies on this subject, e.g. those by Ascher et al. (2001), Cameron and Mardulyn (2001), Engel (2001a, b), Schultz et al. (2001) and Noll (2002). Therefore, the arrangements shown here for the outgroup taxa should not be taken as evidence for or against any of these hypotheses, especially because our taxa sampling is rather inadequate for this purpose.

Meliponini came out as a monophyletic group, with a high jackknife and bootstrap support (100\%). Four main clades within Meliponini can be recognized in the consensus tree: (A) Hypotrigona, (B) Austroplebeia, (C) the remaining African genera (Plebeina, Meliplebeia and Axestotrigona) plus the two Oriental genera (Lepidotrigona and Heterotrigona) and (D) the Neotropical genera. However, none of the basal arrangements are supported by jackknife and bootstrap values higher than $50 \%$.

The maximum likelihood analysis resulted in one tree (Fig. 2) with a -Ln score of 4817.06398. The relationships within Meliponini differed in several aspects from those reconstructed under parsimony, especially for the arrangements at the base of the tree. Despite these incongruencies, the large Neotropical clade and several other smaller groups were recovered in both analyses (compare Figs. 1 and 2).

The main difference between the results from the parsimony and ML analyses was the basal group formed by Hypotrigona, Lepidotrigona and Austroplebeia in the ML tree. However, Hypotrigona, Lepidotrigona and Austroplebeia symei contributed the shortest sequences in the dataset, (320, 340 and 338 bp respectively). Additional sequence data from multiple genes will be needed to clearly resolve these basal relationships. Considering that morphological and biogeographical evidence also supports a closer relationship between Lepidotrigona and Heterotrigona than for Lepidotrigona and Hypotrigona, our discussion focuses on the parsimony results.

\section{DISCUSSION}

The analyses of the 16S rDNA partial sequences conducted in the present study 


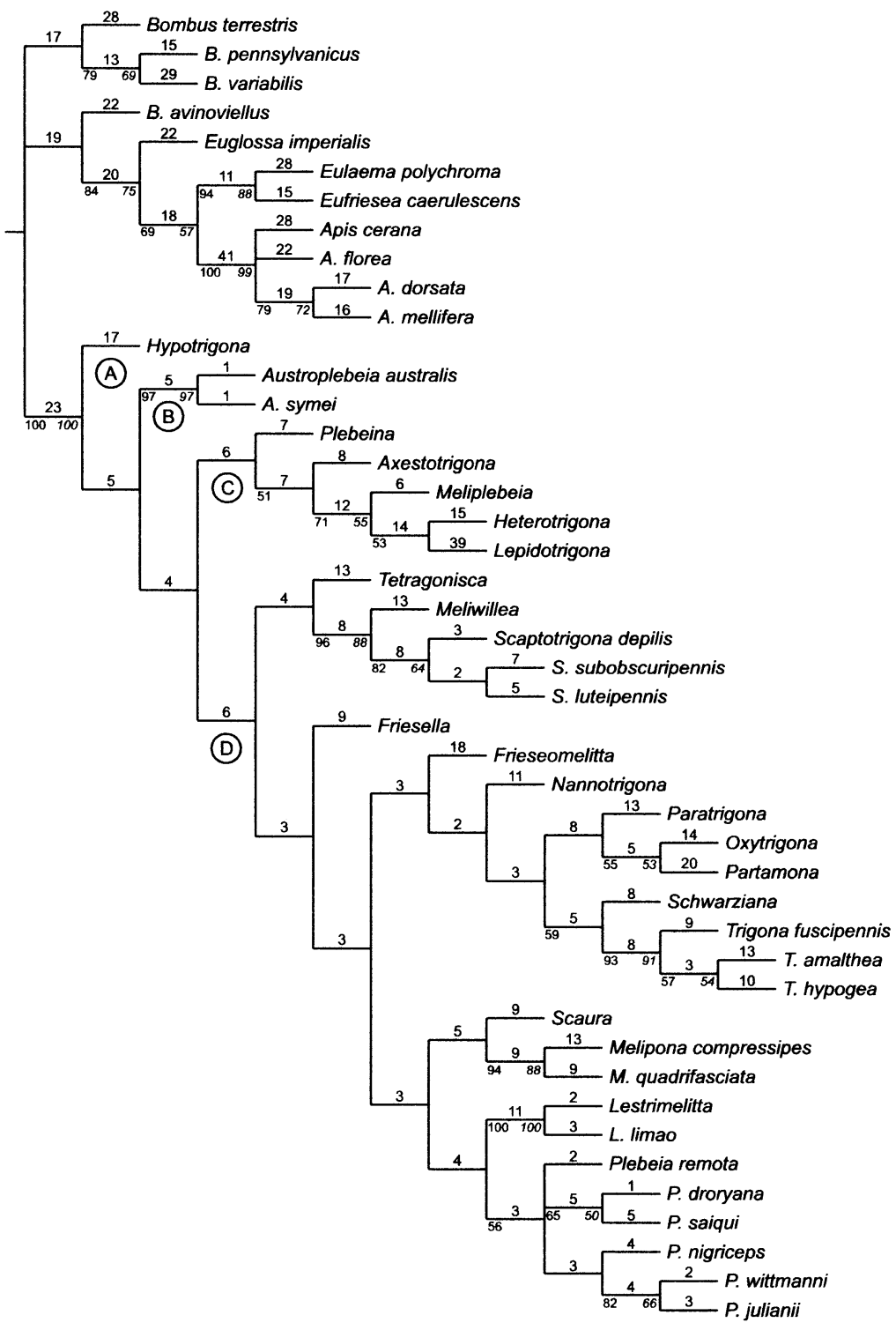

Figure 1. Strict consensus of the 6 most parsimonious trees. The four main clades of the ingroup are indicated within the circles [A. Hypotrigona (Africa), B. Austroplebeia (Australia), C. remaining African and Oriental genera, D. Neotropical genera]. The numbers above lines are branch lengths and those below are jackknife (left) and bootstrap values above 50\% (right). Tree length $=907, \mathrm{CI}=0.33, \mathrm{RI}=0.55$.

indicated phylogenetic relationships for the major groups of Meliponini that differ significantly from previous hypotheses based on adult worker morphology. Traditional groups with intercontinental composition, e.g. Plebeia sensu lato (Moure, 1951, 1961 - including Neotropical and African genera) or Trigona sensu lato (Michener, 1990, 2000 including Neotropical and Oriental genera) were not recovered in our analyses, nor were sister group relationships between Neotropical and African or Oriental faunas. 


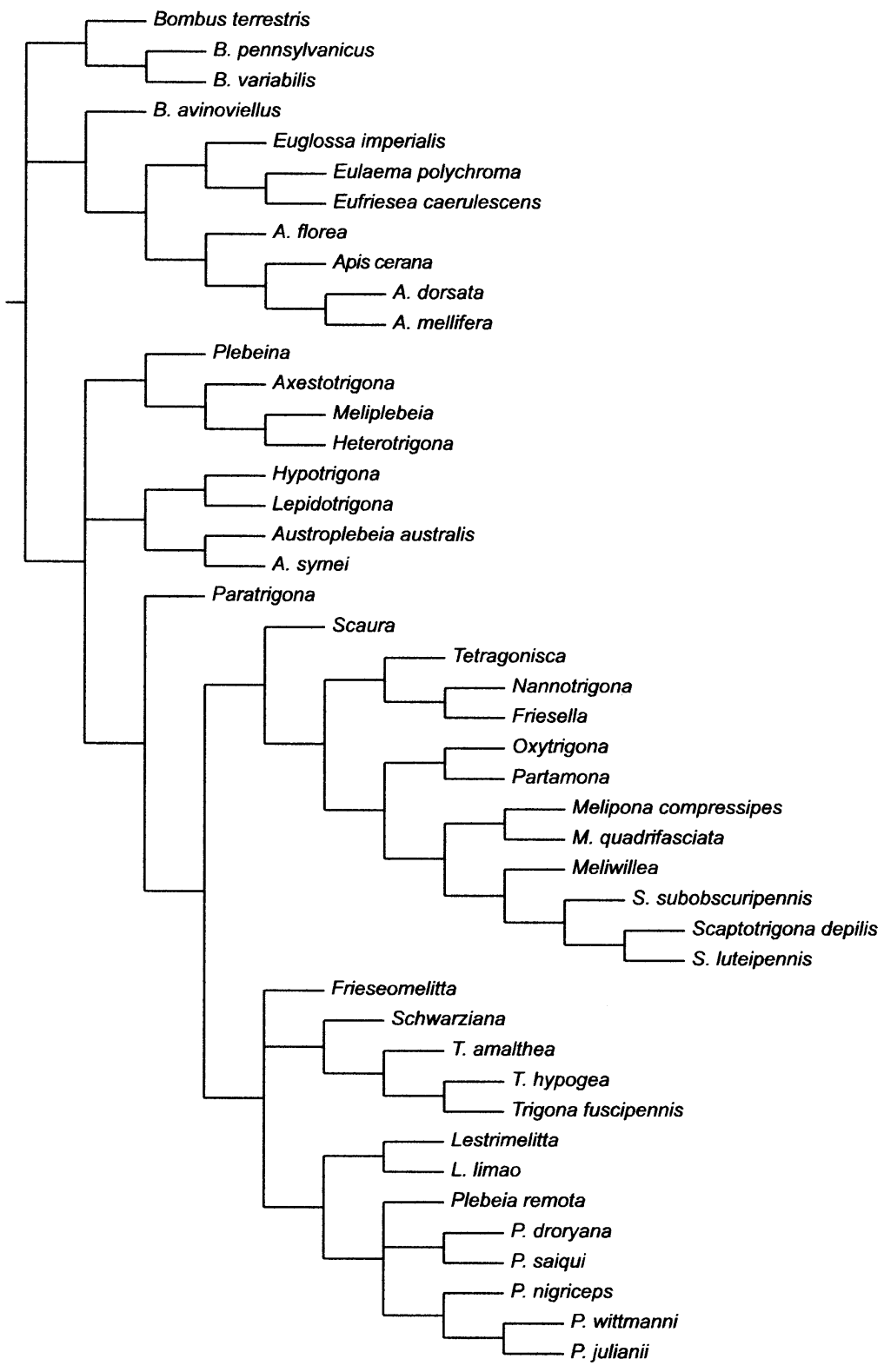

Figure 2. Maximum-likelihood tree obtained under a transversional model with gamma distributed rates $(\mathrm{TVM}+\mathrm{G}) .-\mathrm{Ln}$ score $=4817.06398$.

For comparison, the stingless bee taxa used in the present study were arranged accordingly to the hypotheses presented by Michener (1990) (Fig. 3) and Camargo and Pedro (1992a) (Fig. 4). Optimizing the 16S data set on these trees revealed that their arrangements are considerably less parsimonious (613 and 596 steps in length, respectively) when compared to the hypothesis obtained with the $16 \mathrm{~S}$ sequences (515 steps).

The basalmost position for the African genus Hypotrigona (branch A, Fig. 1) supports 


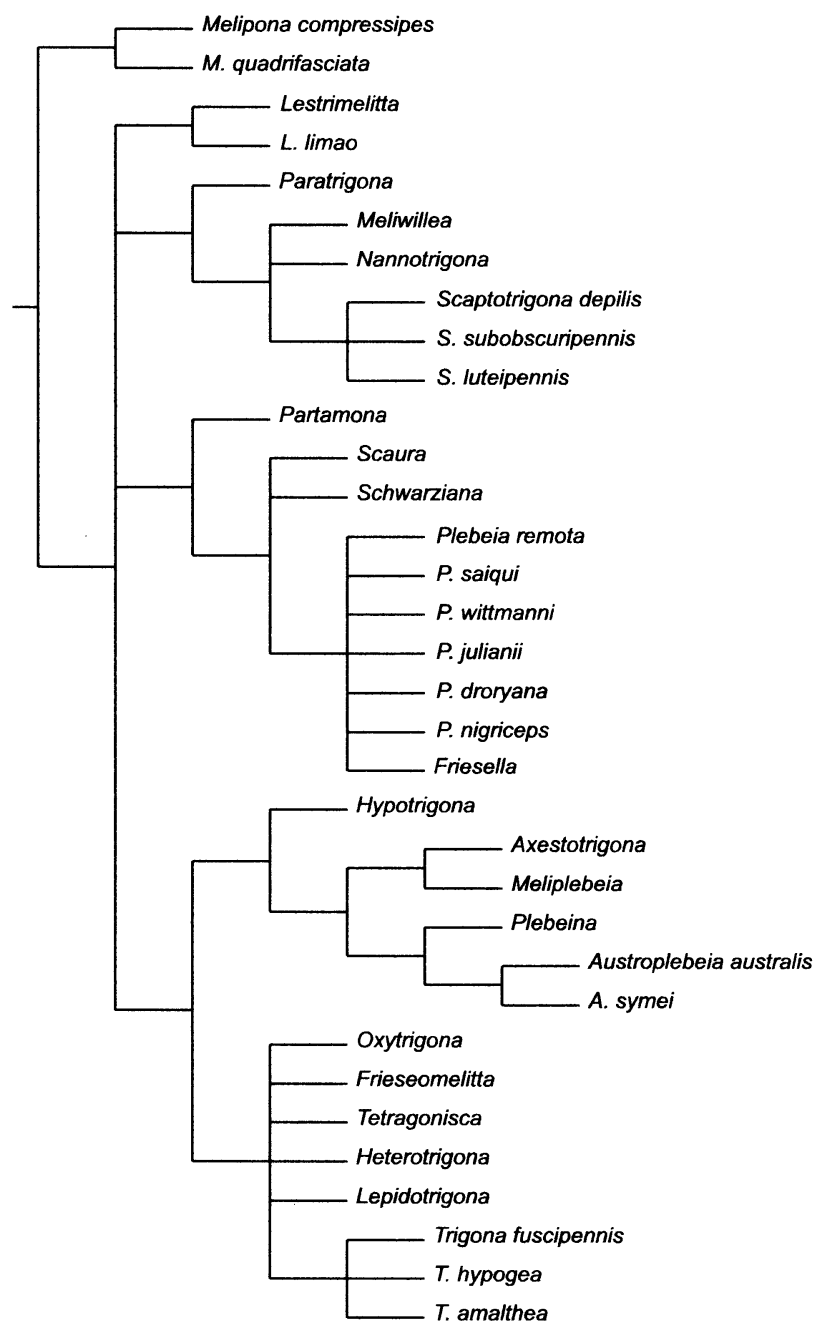

Figure 3. Tree showing relationships among stingless bee taxa used in the present study arranged accordingly to the hypothesis presented by Michener (1990).

the previous suggestion by Michener (1990) that this genus could be the sister group to all the other genera of Meliponini, a hypothesis based on the putatively plesiomorphic mandibular and sternal features of the male. Unfortunately, other genera likely to come out as basal groups within Meliponini, as e.g. Liotrigona (African), Pariotrigona (Oriental) and Trigonisca (Neotropical), could not be included in our analysis due to lack of adequate material for DNA extraction. Although all Meliponini lacks the mesoscutal supra-alar carina (Michener, 1990), these genera contain the only stingless bee species in which the groove associated with the carina is still present (Melo, unpublished data).

Austroplebeia, a genus proposed by Moure (1961) for a group of species restricted to Australia and New Guinea, came out in the parsimony analysis as the second most basal branch within the Meliponini (branch B, Fig. 1). Its isolated geographic distribution lends support to this placement. This result disagrees with Moure's original suggestion of a close relationship between Austroplebeia and the Neotropical Plebeia. His view, 


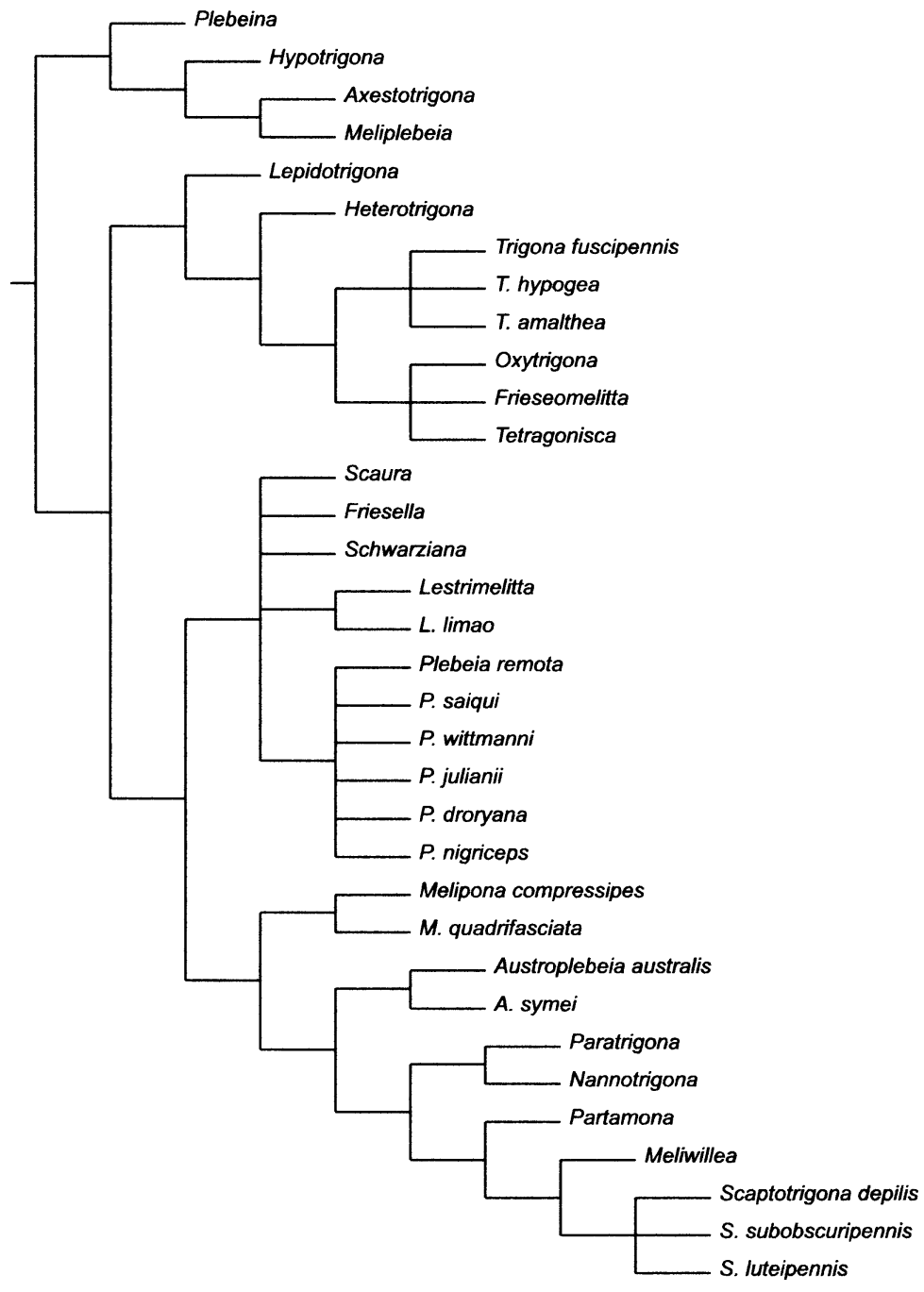

Figure 4. Tree showing relationships among stingless bee taxa used in the present study arranged accordingly to the hypothesis presented by Camargo and Pedro (1992a).

somewhat supported by Camargo and Pedro (1992a, b), was mainly based on the shape of the keirotrichiate area on the inner surface of the worker hind tibia. Michener (1990), however, suggested a different hypothesis placing Austroplebeia as closely related to the African genera based on morphology of the worker gonostyli. Our result, on the other hand, does not support either of the previous hypotheses and suggests that the similarities in the morphology of the keirotrichiate area and gonostylus might represent plesiomorphies.
Heterotrigona and Lepidotrigona, the two Oriental representatives of the Trigona sensu Michener (1990) in our data set, came out as sister groups in the parsimony analysis. These two taxa were nested within a larger clade containing the African genera Plebeina, Axestotrigona and Meliplebeia (branch $\mathrm{C}$ in Fig. 1). Although the whole clade had neither jackknife nor bootstrap support higher than $50 \%$, two of the internal branches did, in particular the branch connecting Meliplebeia with Heterotrigona + Lepidotrigona. 
This close association between the Oriental and African taxa might seem unlikely considering the morphological features used by Michener (1990) to support the monophyly of both an African clade and Trigona sensu lato. Nevertheless, the morphological evidence should be interpreted with caution. Dactylurina, for example, was for a long time considered the only African representative of Trigona s.l. because of its elongated body shape, shiny integument, narrow keirotrichiate ridge and plumose setae along posterior margin of hind tibia (e.g. Moure, 1961). The morphology of the worker sting rudiments and male genitalia, however, led Michener (1990) to include Dactylurina among the other African taxa as the sister group of Plebeina.

Additional support for a closer relationship between African and Oriental taxa also comes from the relatively high number of paleotropical groups of bees with no representatives in the Neotropical region, e.g. the tribes Allodapini and Ctenoplectrini and the genus Apis. There is no known case of a bee group occurring only in the Oriental and Neotropical regions and lacking from Africa. In this regard, Trigona sensu Michener would be an exception. Therefore, recovering a monophyletic Neotropical clade (branch D, Fig. 1) was not surprising. This does not mean, however, that the whole Neotropical meliponine fauna would constitute a monophyletic group, since Trigonisca and related forms were not included in the analysis. There is morphological evidence that this Neotropical group might represent one of the basal branchs in Meliponini (see above).

Regarding the arrangements among the 15 Neotropical genera, our results do not support the main groups traditionally recognized within the Neotropical fauna (see Figs. 3 and 4), although some smaller groups with strong morphological support were recovered in the present analysis, e.g. the clade formed by the genera Meliwillea and Scaptotrigona. This relationship had a high jackknife and bootstrap support corroborating the hypothesis proposed by Roubik et al. (1997). In addition, alternative phylogenetic relationships were suggested for some Neotropical taxa as shown in Figure 1: (1) Lestrimelitta, a genus of obligatory robber bees, was placed as closely related to the genus
Plebeia s. str.; (2) the Plebeia-like genus Schwarziana was placed close to the genus Trigona s. str; (3) Friesella, another Plebeialike genus, was placed distantly from Plebeia; (4) Oxytrigona, a group traditionally included among the Trigona s.l. (e.g. Moure, 1951; Michener, 1990, 2000; Camargo, 1996) came out together with Partamona; and (5) Melipona, a morphologically and behaviorally isolated group within Meliponini, was deeply nested within the Neotropical clade.

The placement of Lestrimelitta as sister group of Plebeia s. str. in our cladograms also has some support from morphological data. The inner surface of the worker hind tibia of Lestrimelitta possesses a narrow, slightly depressed posterior rim, resembling that of Plebeia, a condition that, according to Michener (1990), may be indicative of derivation from a common ancestor.

Plebeia sensu Michener includes several taxa recognized as distinct genera by other authors (e.g., Moure, 1951; Camargo and Pedro, 1992a, b). Michener (1990, 2000) emphasized the morphological similarities of these taxa and downweighted the small number of characters used by Moure (1951) to separate the groups. Four of these genera were included in our analysis, Plebeia, Schwarziana, Friesella, and Scaura. The results obtained here favor recognition of generic status for these groups since they did not form a monophyletic clade as one would expect if Michener's character weighting was correct.

The position of Melipona in our phylogenetic analysis, as one of the most apical branches, is congruent with Camargo and Pedro's (1992a, b) hypothesis (see Fig. 4). This is one of the most specialized groups within Meliponini, exhibiting several autapomorphic morphological and behavioral features. Melipona has been traditionally placed as an isolated group within the tribe because of its unique features (e.g. Moure, 1951; Michener, 1990, 2000). Our results, therefore, do not support the somewhat aberrant position for Melipona as the most basal branch of the Meliponini in Michener's phylogeny.

This first investigation into the molecular phylogeny of the stingless bees provided only limited support to the previous morphologybased hypotheses. More importantly, it 
suggested new alternative relationships among the included taxa. We are aware that some of these relationships are poorly supported and should be carefully reevaluated in future studies. An improved resolution of the present phylogeny is likely to be obtained by analyzing a larger number of meliponine taxa, larger fragments, and by obtaining sequence information from other regions of the genome, in particular nuclear genes. In addition, molecular and morphological data should be jointly analyzed in future investigations. Unfortunately, the currently available information on morphological characters for Meliponini are not detailed enough to allow a robust combined analysis and gathering the necessary morphological data was beyond the scope of the present study.

\section{ACKNOWLEDGMENTS}

This reasearch received financial support from the Brazilian Research Councils CNPq (Conselho Nacional de Desenvolvimento Científico e Tecnológico) and CAPES (Fundação Coordenação de Aperfeiçoamento de Pessoal de Nível Superior). We thank Ronaldo Zucchi, Charles D. Michener, Lucio A.O. Campos, Ben Oldroyd and Patricia M. Drumond for providing sample material and J.M.F. Camargo for comments on the early results. An earlier version of the manuscript was improved by comments from Charles D. Michener.

Résumé - Phylogenèse moléculaire des abeilles sans aiguillon (Apidae, Apinae, Meliponini) déduite des séquences d'ADN mitochondrial codant pour l'ARNr 16S. Les données des séquences de l'ADN mitochondrial codant pour l'ARN ribosomal $16 \mathrm{~S}$ de 34 espèces recouvrant 22 genres ont été utilisées pour étudier les relations phylogénétiques parmi les abeilles sans aiguillon (tribu des Meliponini). On a inclu comme groupes extérieurs les séquences disponibles de quatre espèces d'Apis, quatre espèces de Bombus et trois espèces d'Euglossini (Tab. I). Des analyses de parcimonie sans pondération et du maximum de vraisemblance ont été faites sur une série de données constituées de 462 positions de bases alignées. L'analyse de parcimonie a fourni six arbres également parcimonieux (901 pas, $\mathrm{CI}=0,33$ et $\mathrm{RI}=$ $0,55)$. L'analyse du maximum de vraisemblance a fourni un arbre dans lequel les relations entre Meliponini différaient sous plusieurs aspects de celles reconstruites par la parcimonie, principalement dans l'organisation à la base de l'arbre. En dépit de ces incongruences, le grand rameau néotropical et plusieurs autres groupes plus petits se ret- rouvaient dans les deux analyses (Figs. 1 et 2). Dans l'arbre consensus on peut reconnaitre quatre rameaux principaux (Fig. 1) : (A) Hypotrigona, (B) Austroplebeia, $(\mathrm{C})$ les autres genres africains (Plebeina, Meliplebeia et Axestotrigona) plus les deux genres orientaux (Lepidotrigona et Heterotrigona) et (D) les genres néotropicaux. Le genre africain Hypotrigona a été placée sur la branche la plus basale dans la tribu, suivie d'Austroplebeia en tant que groupe sœur des deux principaux rameaux (C et D). Ces résultats ne concordent pas avec les groupes traditionnels à la composition intercontinentale, par exemple Trigona sensu lato ou Plebeia sensu lato. Si l'on considère les groupements parmi les 15 genres néotropicaux, nos résultats ne concordent pas avec les principaux groupes traditionnellement reconnus au sein de cette faune, bien qu'on ait retrouvé certains petits groupes aux caractéristiques morphologiques fortes, par exemple le rameau formé par le genre Meliwillea et Scaptotrigona. Les relations phylogénétiques alternatives suivantes ont été par ailleurs suggérées: (1) Lestrimelitta, genre d'abeilles voleuses obligatoires, a été placée comme étroitement apparentée à Plebeia s. str., (2) le genre semblable à Plebeia, Schwarziana, a été placé près du genre Trigona s. str., (3) Friesella, autre genre semblable à Plebeia, a été placé loin de Plebeia, (4) Oxytrigona, groupe traditionnellement inclus dans Trigona s.l. (Moure, 1951 ; Michener, 1990, 2000 ; Camargo, 1996) formait un groupe avec Partamona et (5) Melipona, groupe isolé du point de vue morphologique et comportemental au sein des Meliponini, était situé au milieu du rameau néotropical.

\section{abeilles sans aiguillon / Meliponini / phylogénie /} ADNr 16S

Zusammenfassung - Ableitung der molekularen
Phylogenie der Stachellosen Bienen (Apidae, Apinae, Meliponini) auf Grund von mitochondrialen 16S rDNA Sequenzen. Mit Sequenzdaten mitochondrialer $16 \mathrm{~S}$ rDNA von 34 Arten (22 Gattungen) wurde die phylogenetische Verwandtschaft bei Stachellosen Bienen (Stamm Tribus Meliponini) untersucht. Die Sequenzen von 4 Arten von Apis, 4 Arten von Bombus und 3 Arten der Euglossini wurden als "outgroups" zur Untersuchung herangezogen (Tab. I). Gleich gewichtete (equally weighted) Parsimony und Maximum-LikelihoodAnalysen wurde bei einem Datensatz von 462 aligned Basenpositionen angewendet. Die Parsimony Analyse ergab 6 Bäume höchster Parsimony (901 Schritte; $\mathrm{CI}=0.33$ und RI $=0.55$ ). Die MaximumLikelihood-Analyse ergab einen Baum, in dem sich die Verwandtschaft innerhalb der Meliponini in mehreren Aspekten von der durch Parsimony erhaltenen Verwandtschaft unterschied, vor allem 
in der Anordnung in den Basisgruppen. Trotz dieser Inkongruenz wurde der große neotropische Zweig und verschiedene andere kleinere Gruppen in beiden Analysen aufgetrennt (Abb. 1 und 2). Im Parsimony Consensus Baum können vier Hauptzweige erkannt werden (Abb. 1): (A) Hypotrigona, (B) Austroplebeia, (C) noch vorhandene afrikanische Gattungen (Plebeina, Meliplebeia, und Axestotrigona) zusammen mit den beiden orientalischen Gattungen (Lepidotrigona and Heterotrigona), und (D) neotropischen Gattungen. Die afrikanische Gattung Hypotrigona befand sich am untersten Ast innerhalb des Tribus, gefolgt von Austroplebeia als Schwestergruppe der beiden Hauptäste (C und D). Diese Ergebnisse unterstützen die traditionelle Gruppierung nach Kontinenten nicht, e.g. Trigona sensu lato oder Plebeia sensu lato. Wurde die Gruppierung bei den 15 neotropischen Gattungen betrachtet, unterstützten unsere Ergebnisse auch nicht die Hauptgruppen, die allgemein innerhalb dieser Fauna anerkannt sind, auch wenn einige kleinere Gruppen mit starken morphologisch bedeutenden Daten erkannt wurden, e.g. der Ast, der aus den Gattungen Meliwillea und Scaptotrigona besteht. Zusätzlich wurden folgende alternative phylogenetische Verwandtschaften vorgeschlagen: (1) Lestrimelitta, eine Gattung von obligatorischen Räuberbienen, lag als nahe verwandt bei der Gattung Plebeia s. str.; (2) die Plebeiaähnliche Gattung Schwarziana wurde nahe an der Gattung Trigona s. str. plaziert; (3) Friesella, eine andere Plebeia-ähnliche Gattung lag entfernt von Plebeia; (4) Oxytrigona, eine traditionell innerhalb der Trigona s.l. liegende Gruppe (e.g. Moure, 1951; Michener, 1990, 2000; Camargo, 1996) bildete einen Kluster mit Partamona; und (5) Melipona, eine innerhalb der Meliponini morphologisch und vom Verhalten isolierte Gruppe lag mitten in dem neotropischen Ast.

\section{Stachellose Bienen / 16S rDNA / Phylogenie / Meliponini}

\section{REFERENCES}

Ascher J.S., Danforth B.N., Ji S. (2001) Phylogenetic utility of the major opsin in bees (Hymenoptera: Apoidea): a reassessment, Mol. Phylogenet. Evol. 19, 76-93.

Camargo J.M.F. (1996) Meliponini Neotropicais: o gênero Camargoia Moure, 1989 (Apinae, Apidae, Hymenoptera), Arq. Zool. 33, 71-92.

Camargo J.M.F., Pedro S.R.M. (1992a) Sistemática de Meliponinae (Hymenoptera, Apidae): sobre a polaridade e significado de alguns caracteres morfológicos, in: Cruz-Landim C., Chaud-Netto J. (Eds.), Anais do Encontro Brasileiro de Biolo- gia de Abelhas e outros Insetos Sociais, Ed UNESP, São Paulo, pp. 45-49.

Camargo J.M.F., Pedro S.R.M. (1992b) Systematics, phylogeny and biogeography of the Meliponinae (Hymenoptera, Apidae): a mini review, Apidologie 23, 293-314.

Cameron S.A. (1991) A new tribal phylogeny of the Apidae inferred from mitochondrial sequences, in: Smith D.R. (Ed.), Diversity in the Genus Apis, Westview Press, Boulder, pp. 71-78.

Cameron S.A. (1993) Multiple origins of advanced eusociality in bees inferred from mitochondrial DNA sequences, Proc. Natl. Acad. Sci. USA 90, 8687-8691.

Cameron S.A., Mardulyn P. (2001) Multiple molecular data sets suggest independent origins of highly eusocial behavior in bees (Hymenoptera: Apinae), Syst. Biol. 50, 194-214.

Crozier R.H., Crozier Y.C. (1993) The mitochondrial genome of the honeybee Apis mellifera: complete sequence and genome organization, Genetics 133, 97-117.

Derr J.N., Davis S.K., Wooley J.B., Wharton R.A. (1992a) Variation and the phylogenetic utility of the large ribosomal subunit of mitochondrial DNA from the insect order Hymenoptera, Mol. Phylogenet. Evol. 1, 136-147.

Derr J.N., Davis S.K., Wooley J.B., Wharton R.A. (1992b) Reassessment of the 16S rRNA nucleotide sequence from members of the parasitic Hymenoptera, Mol. Phylogenet. Evol. 1, 338341.

Dowton M., Austin A.D. (1994) Molecular phylogeny of the insect order Hymenoptera: Apocritan relationships, Proc. Natl. Acad. Sci. USA 91, 9911-9915.

Dowton M., Austin A.D. (2001) Simultaneous analysis of $16 \mathrm{~S}, 28 \mathrm{~S}$, COI and morphology in the Hymenoptera: Apocrita: Evolutionary transitions among parasitic wasps, Biol. J. Linn. Soc. 74, $87-$ 111.

Dowton M., Austin A.D., Dillon N., Bartowsky E. (1997) Molecular phylogeny of the apocritan wasps: the Proctotrupomorpha and Evaniomorpha, Syst. Entomol. 22, 245-255.

Engel M.S. (2001a) A monograph of the Baltic amber bees and evolution of the Apoidea (Hymenoptera), Bull. Am. Mus. Nat. Hist. 259, 1-192.

Engel M.S. (2001b) Monophyly and extensive extinction of advanced eusocial bees: Insights from an unexpected Eocene diversity, Proc. Natl. Acad. Sci. USA 98, 1661-1664.

Farris J.S., Albert V.A., Källersjö M., Lipscomb D., Kluge A.G. (1996) Parsimony jackknifing outperforms neighbor-joining, Cladistics 12, 99124.

Koulianos S., Schmid-Hempel R., Roubik D.W., Schmid-Hempel P. (1999) Phylogenetic relation ships within the corbiculate Apinae (Hymenoptera) and the evolution of eusociality, J. Evol. Biol. $2,380-384$. 
Michener C.D. (1944) Comparative external morphology, phylogeny and classification of the bees, Bull Am. Mus. Nat. Hist. 82, 151-326.

Michener C.D. (1974) The Social Behavior of the Bees, Harvard Univ. Press, Cambridge.

Michener C.D. (1990) Classification of the Apidae (Hymenoptera), Univ. Kansas Sci. Bull. 54, 75164.

Michener C.D. (2000) The Bees of the World, Johns Hopkins Univ. Press, Baltimore.

Moure J.S. (1951) Notas sobre Meliponinae (Hymenoptera, Apoidea), Dusenia 2, 25-50.

Moure J.S. (1961) A preliminary supra-specific classification of the old world Meliponinae bees (Hymenoptera, Apidae), Studia Entomol. 4, 181242.

Noll F.B. (2002) Behavioral phylogeny of corbiculate Apidae (Hymenoptera; Apinae), with special reference to social behavior, Cladistics 18, 137153

Posada D., Crandall K.A. (1998) MODELTEST: testing the model of DNA substitution, Bioinformatics 14, 817-818.

Posada D., Crandall K.A. (2001) Selecting the best-fit model of nucleotide substitution, Syst. Biol. 50, 580-601.

Roubik D.W., Segura J.A.L., Camargo J.M.F. (1997) New stingless genus endemic to Central American cloudforests: phylogenetic and biogeographic implications (Hymenoptera: Apidae: Meliponini), Syst. Entomol. 22, 67-80.

Sakagami S.F. (1982) Stingless bees, in: Hermann H.R. (Ed.), Social Insects, Vol. III, Academic Press, New York, pp. 361-423.
Sanger F.S., Nicklen S. Coulson A.R. (1977) DNA sequencing with chain terminator inhibitors, Proc. Natl. Acad. Sci. USA 74, 5463-5467.

Schultz T.R., Engel M.S., Ascher J.S. (2001) Evidence for the origin of eusociality in the corbiculate bees (Hymenoptera:Apidae), J. Kans. Entomol. Soc. 74, 10-16.

Schwarz H.F. (1948) Stingless bees (Meliponidae) of the Western Hemisphere, Bull. Am. Mus. Nat. Hist. 90, 1-546.

Sheppard W.S., McPheron B.A. (1991) Ribosomal DNA diversity in Apis, in: Smith D.R. (Ed.), Diversity in the Genus Apis, Oxford, Westview Press, Boulder, pp. 89-107.

Swofford D.L. (2001) PAUP*. Phylogenetic Analysis Using Parsimony (*and Other Methods), Version 4, Sinauer Associates, Sunderland, Massachusetts.

Tanaka H., Roubik D.W., Kato M., Liew F., Gunsalam G. (2001) Phylogenetic position of Apis nuluensis of northern Borneo and phylogeography of A. cerana as inferred from mitochondrial DNA sequences, Insectes Soc. 48, 44-51.

Thompson J.D., Higgins D.G., Gibson T.J. (1994) CLUSTAL W: improving the sensitivity of progressive multiple sequence alignment through sequence weighting, positions-specific gap penalties and weight matrix choice, Nucl. Acids Res. 22, 4673-4680.

Wille A. (1979) Phylogeny and relationships among the genera and subgenera of stingless bees (Meliponinae) of the world, Rev. Biol. Trop. 27, 241-277.

Wille A. (1983) Biology of the stingless bees, Annu. Rev. Entomol. 28, 41-64. 